\title{
Ethnicity and Ethnic Politics: An Impediment to Political Development in Nigeria
}

\author{
Adeleke Adegbami ${ }^{1} \&$ Charles I. N. Uche ${ }^{2}$ \\ ${ }^{1}$ Department of Public Administration, Obafemi Awolowo University, Ile-Ife, Nigeria \\ 2 Department of Public Administration, Oduduwa University, Ipetumodu, Nigeria \\ Correspondence: Adeleke Adegbami, Department of Public Administration, Obafemi Awolowo University, \\ Ile-Ife, Nigeria. Tel: 234-80-3405-6781. E-mail: adeadegbami@yahoo.com
}

\author{
Received: January 29, 2015 Accepted: February 12, 2015 Online Published: April 27, 2015 \\ doi:10.5539/par.v4n1p59 \\ URL: http://dx.doi.org/10.5539/par.v4n1p59
}

\begin{abstract}
Nigeria with over 300 ethnic groups, over 1000 dialects, who practiced several religions, with different cultures and histories came under the British imperialist in the 19th century. With the 1st January, 1914 amalgamation of Southern and Northern Protectorate the foundation of a nation now called Nigeria was laid. Nigeria is now populated by over 166 million people, adopted federal system of government with 36 States and a Federal Capital Territory. Despite these component States, Nigeria could still be seen peripherally as a nation with tripodal ethnic structure with the trio of Yoruba, Hausa/Fulani and Igbo constituting a pole each in the unceasing struggle for political and economic resources of the nation. The existing cleavages and hegemonic nature of the Yoruba, Hausa/Fulani and Igbo (major ethnic groups) metamorphosed into a 'monster-seed' germinated into hydra headed monster tormenting and straining the nation's political developments. Apart from inter-ethnic conflicts, there are also intra-ethnic conflicts among these major ethnic groups and other allied minority ethnic groups resulting from unending political manipulation, manoeuvrings, calculations and permutation. The study revealed that, the alliances and coalitions between/among political parties to have overall majority needed to win election(s) are based on ethnic sentiments and ethnic gang-up. The study further revealed the attendant effects of ethnic politics to include- emergence of incompetent political leaders who are not committed to the development of the nation; inability to choose leaders with national outlook or national acceptability; disconnected leaders (self-centred/self-seeking leaders); mediocre in governance; and corrupt leaders being supported by ethnic groups. The sentiment attached to the issues of corruption among political leaders has snowballed to a situation whereby corruption has permeated all levels of government in Nigeria, keeping down about 90 million Nigerians in perpetual poverty. It has equally cost Nigerians whooping sum of over $£ 20$ Billion Pounds (about \$500 Billion) stolen since independence by past leaders of the country and still counting. Money which could have been used to develop Nigeria has vanished to the pocket of the so called ethnic political leaders with their various towns and villages remaining undeveloped. The study recommended that, Nigerian should imbibe the spirit of oneness and stamp out ethnicity in the conduct of affairs of the nation, in order to experience national unity and peace which are essential ingredients for nation's development, progress, stability and national integration.
\end{abstract}

Keywords: ethnicity, ethnic politics, political development, cleavages, political party, ethnic affiliation, ethnic gang-up

\section{Introduction}

Nigeria most populous African nation and one of the world's most diverse countries covers an area of 923,768 sq. $\mathrm{km}$. on the shores of the Gulf of Guinea. To its West side is Benin Republic, Niger on the North, Chad to the North-East, Cameroon to the East and South-East. Nigeria came under the British imperialist during the 19th century and with the 1st January, 1914 amalgamation of Southern and Northern Protectorate the foundation of a nation now called Nigeria was laid.

The amalgamation which was brought about for administrative convenience was followed by protests from different peoples who were forced to live together without taking into consideration their differences in languages, culture, belief and tradition. Among different nations that were fused together incongruously were the Kanuri, Hausa, Fulani, Efik, Igala, Tiv, Jukun, Nupe, Yoruba, Edo, Ibibio, and Ijaw. As a result, Nigeria is populated by over 300 ethnic groups, (Okotoni, 2006), out of which Hausa/Fulani, Yoruba and Igbo were predominant. 
The Hausa/Fulani, Yoruba and Igbo thus established their dominion in the Northern, Southern and Eastern regions of Nigeria respectively. At Independence in 1960, these three groups dominance in their regions led to minority ethnic groups' agitation for the creation of more states with the intention of weakening the dominant posture of Hausa/Fulani, Yoruba and Igbo (Ekpo, 2010). To this extent, the country which had only three regions at independence in 1960 has now metamorphosed into thirty-six States and separate Federal Capital Territory by October 1996.

Despite the breaking down of Nigeria into 36 States with FCT, the politics being practiced in Nigeria is that of politics of ethnicity, gang-up politics and political party with ethnic affiliation. The incessant struggle for power among these diverse ethnic groups is having far reaching impact on the corporate existence of the nation, vis a vis the attendant conflicts and insecurity which is daily shaking the feet of the nation. It is against this background that the study examines the complex nature of Nigeria in the area of ethnicity and ethnic politics/gang-up and effects of this type of politics on the political development of the nation.

\section{Clarification of Concept: Ethnicity}

Ethnicity is a ubiquitous phenomenon which is not limited to the developing world but can also be found in the developed countries. This is because many villages, bands and isolated communities due to one reason or the other came together to form a nation and then maintained their cultural practices even within the newly formed entity (Cohen, 1974). These entities later metamorphosed into ethnic groupings within a state with different degrees of cultural uniqueness and distinctiveness.

The concept of ethnicity has been variously defined by scholars; Cohen (1974) for instance avers that an ethnic group is a collection of people who share some patterns of normative behaviour and form a part of a larger population, interacting with people from other ethnic groups within the framework of a social system. For Cohen, one of the characteristics of a people so addressed as an ethnic group is the "sharing of normative behaviour". This normative behaviour is a distinct behaviour which distinguished one group of people from others and it include; kingship, marriage, friendship, festival, rituals and other similar ceremonial activities. Normative behaviour can also be coupled to the continuous interactions with other distinguished group especially within the same Nation-State. Therefore ethnicity can be seen as interaction between culturally distinct groups operating within a common social context.

For McLean (1991) ethnic group is the strongest sense of group feeling. From this simple definition, it can be deduced that there are many groups to which men could belong. These groups include- social, political, religious and professional groups -of which the ethnic group stimulates the greatest feelings especially among those who are biologically related. To this extent, Primordialists have argued that ethnic groups are the outcome of biological processes (Fearon and Laitin, 2000a). Thus, blood is a unifying factor in cementing the relationship among the ethnic group as membership is not by choice but rather by descent. Lending credence to the unifying "power of blood relationships" Udo (1980) highlights the power of blood in cementing relations among ethnic groups even after the political partitioning and demarcation of nations. It is evident that, the political demarcation which followed the eventual partitioning of African territories by the colonial powers is not a barrier to ethnic ties and relation. According to Udo (1980:10 cited in Salami, 2004)

the cultural tie between the Hausa of Nigeria and Niger may be greater than contacts between Hausa of Nigeria and Jukun of Nigeria.

To Gordon (1964) ethnic group is any group which is defined or set apart by race, religion or a defined origin or combination of some of these categories. For instance, an ethnic group like the Yoruba is said to be descendants of Oduduwa with its ancestral home at Ile-Ife. Rose (1965) avers that an ethnic group comprises people who share a unique social and cultural heritage which is passed from one generation to the other. Ethnic group is identified by distinctive patterns of family life language, recreation, religion and other customs which differentiate them from others. Therefore, ethnicity is a continuum as its characteristics remains from generation to generation. Ethnic group according to Sanda (1976) consists of interacting members who belong to a named or labelled social group with whose interest they identify, and which manifests certain aspects of a unique culture while constituting a part of a wider society. The recent happenings in Nigeria have brought this definition to the fore as ethnicity has become a veritable tool and basis for canvassing for political as well as economic power.

In Anugwom's (2000) view, ethnicity should be seen as arising in any situation in which a group of people, no matter their size, with different cultural and linguistic attributes from those of its neighbours uses this as the basis of group solidarity and interaction with others. In so doing, the group sees itself not only as distinct, but as a "group in itself and for itself". Thus, group consciousness is the most crucial factor in the definition of an ethnic group and ethnicity involves one group seeing other groups as relatively inferior to its self as well as being rivals. This feeling 
consequently brings about attitudes which distort reality and breed subjectivity in the evaluation and perception of events. Ethnicity, Anugwom further states, often contains an obscured class component. In this sense, it becomes a tool for the elite members of society to hold on to their privileges. Therefore, in Africa, ethnicity implies a situation whereby ethnic movements are created and instigated into action by the elite in a bid to further their own interests (Sklar, 1967).

Azeez (2004) sees ethnicity as a sense of fellow feeling that has its foundation in the combined remembrance of past experience and a common hope and desire for the future. Ethnicity has to do with origin of a people. Thus, it is the existence of the group that makes ethnicity possible as ethnicity does not exist outside the unit or group that embodies it. Ethnicity could also be seen as the employment or mobilisation of ethnic identity and difference to gain advantage in situations of competition, conflict or cooperation (Osaghae, 1995). Thus, for Osaghage, ethnicity is a readymade weapon for actualising group desires within a Nation-State and a careful and deliberate attempt by social actors to outsmart other competing groups in the struggle to control the scarce economic resources of the State. Therefore, ethnicity is not necessarily due to "biological attachment" but the result of the interaction within the external environment (Brubaker, Loveman, and Stamatov, 2004).

\section{Complexities and Nature of Nigeria}

Nigeria comprised of about 166 million people as at 2012 (National Bureau of Statistics, 2012 cited in Trading Economics, 2014), with over 300 ethnic groups, has over 1000 dialects (Okotoni, 2006), practice several religions, and different histories and cultures. These perhaps are some of the reasons for the adoption of federal system of government. Nigeria's ethnic groups could be broadly divided into ethnic 'majorities' and ethnic 'minorities'. The majority ethnic groups are the Hausa-Fulani of the North, the Yoruba of the Southwest, and the Igbo of the Southeast of which their numerical and hegemonic strength within the nation gave Nigeria its tripodal ethnic structure. Each of these three major ethnic groups, thus, constitutes a pole in the struggle for political and economic resources of the nation (Mustapha, 2007). There are also ethnic minorities in the nation who at-times with intention of wrestling to have their share of national cake form alliances to have a formidable force and enough respite against the three dominant ethnicities.

These always generate conflict as the three hegemonic groups also fortify themselves to ensure its dominance in governmental activities. Concerning the level of complexities of Nigeria nation, Mustapha (2007) identified eight major cleavages in which Nigeria could be classified. According to him

The interplay between this tripodal ethnic structure on the one hand, and administrative divisions and communal identities on the other, has led to eight major cleavages in Nigerian political life..., the most important of which are: the cleavages between the three majority groups; between the three majority ethnic groups on the one hand and the 350-odd minority ethnic groups on the other; between the north and south4; between the 36 states of the federation and the six zones-three in the north and three in the south-into which they are grouped; and finally, between different religious affiliations. Some of these cleavages overlap: for example, the southeast zone overlaps with Igbo ethnicity and Christian religious affiliation, while the north-central overlaps with northern ethnic minorities. The ethnic, regional, and religious cleavages in Nigerian society are made more problematic by systematic and overlapping patterns of inequalities that correspond to the cleavages (Mustapha, 2007: $3-4)$.

These eight cleavages grouping could be seen as seed of discord sown, which had germinated into hydra headed monster tormenting and straining the nation's socio-economic activities which has also constituted a nuisance to the political developments of the nation. For instance most of the conflicts in Nigeria were so much attributable to religious, economic and ethnic factors. The deepest problem Nigeria is facing is internal conflict within the same ethnic group. Among the Yoruba for instance, there are Ijebus, Ijeshas, Aworis, Ekitis, Oyos, Egbas to mention but few who constantly contest among themselves for position and power in political as well in the economic wealth of the nation. As it is among the Yoruba so it is among the Hausa/Fulani and the Igbos. Recently, 'some ethnic groups' among the Hausa/Fulanis have expressed their dissatisfaction toward the way they are being maginalised and sidelined in Northern part of the nation. These groups claimed that, the powerful elite in the region had marginalised them and they have been robbed off of their rights of participation in governance (Owete, 2014).

\section{Political Party and Ethnic Affiliation}

Ethnic politics had been on existence since the colonial days in Nigeria. According to Ako-Nai (2008) ethnic 
politics and rivalry could be linked to colonial imperialists who adopted the method of divide and rule to govern. Then ethnic groups were played against one another for economic gain from the British imperialists. Thus, the initial politics of separation by the British imperialists is the bedrock of continued conflict among the major ethnic groups in Nigeria even after independence (Ako-Nai, 2008). From independence also, the dominant ethnic groups in Nigeria (Hausa, Yoruba and Igbo) had been engaged in the activities of controlling the political power of the nation, with the primary aim of controlling the resources of the state. The sole ambition of controlling the economic activities of the nation has led to 'keen hunt', for political power especially at the centre by the various ethnic groups in Nigeria. The political calculation and permutation of who gets what, when, and how of the political cum economic potentialities of the nation are the main sources of hostility and conflicts. This has continued to threatening the political stability and advancement of Nigeria as a nation. The incessant struggle for power is always heating-up the nation's polity. Apart from the fact that this action has continued to polarize the nation along ethnic groups divides, the degree of human losses in every political violence associates with power struggle is unquantifiable.

Nigeria's democracy has been characterized by ethnic-based politics since independence when the set of political parties were being founded; the scenario then was aptly captured by Azeez (2009). According to him

In pre-independence Nigeria, party politics and party formation assumed an ethnic completion, even as it metamorphosed into the post-independent first republic. The Action Group developed from the political wing of the cultural association of the Yoruba educated elite, the Egbe Omo Oduduwa; the NCNC was closely allied with the Ibo state union and played a significant role in the internal affairs of the party, while NPC was founded by the Fulani aristocracy...And more significantly, the division of the country into three regions for administrative convenience by the Richards constitution of 1946 led to the development of strong regional feeling. The consequence of this was such that by 1953, the major political parties in Nigeria-NCNC, AG and NPC, were associated with the major ethnic groups and the three regions, Western, Eastern and the Northern regions (Azeez, 2009:3).

Azeez further argued that the formation of the political parties during this period was tripod in nature such that the party formation was based along three major ethnic groups, with three major ethnic leaders piloting the political activities to strengthening their respective regions. In Azeez's words

To further crystallize the tripartite ethnic cleavages, the party leaderships were structured accordingly, viz: the Sardauna of Sokoto, Sir Ahmadu Bello led the NPC of the North; Dr. Nnamdi Azikwe held the ace for the Igbos NCNC, while Chief Obafemi Awolowo led the AG in the Yoruba West, each representing their ethnic/regional divides (Azeez, 2009:3).

The First Republic saw the initial political parties formation based on ethnic attachment. For instance, Action Group (AG) was tagged with Yoruba ethnic group, led by Chief Obafemi Awolowo in the then Western Nigeria, similarly, the Hausa/Fulani also had her own political party known as Northern Peoples' Congress (NPC) led by Alhaji Abubakar Tafawa Balewa while, the Igbos political party was branded the National Council for Nigerian Citizens (NCNC) led by Nnamdi Azikwe. All these political parties formed by the dominant ethnic groups of Yoruba, Hausa/Fulani and Igbo were regional based political parties pursuing their respective regional agenda and strengthening ethnic politics. The ethnic agenda of the then political parties of Nigeria's First Republic, bred the political turmoil witnessed few years after independence which consequently led to the termination in January 1966, the First Republic by a Military coup d'état. Even the coup was perceived by the Northerners as a sectional coup targeted against the Hausa/Fulanis in order to terminate their political leaders. Confirming this assertion, Orewa (1997:109-110), avers that

It is claimed in some quarters that the Nzeogwu led coup was ethnically-tainted because none of the political leaders who lost their lives in the process was of Igbo stock - the language group of Nzeogwu, the leader...

Ethnic 'military' politics equally manifested itself in the events that unfolded following the first military coup in Nigeria. Series of reprisals among ethnic groups within and outside the military bore testimony to this. One of such reprisals was counter coup that was carried out five months later (in July 1966), by the Hausa/Fulani in the military. This scenario is described by Orewa (1997:110) as follows

The reprisal taken on the Igbo-speaking military officers and other persons of that language group particularly in the Northern Region and in parts of Western Region 
which led to their fleeing in large numbers to their enclaves in the then Eastern and Midwestern Regions did not help matters.

Consequently, Nigeria was ruled by different military regimes that lasted till October 1, 1979 when the civilian administration returned after thirteen years of military rule.

In the Second Republic, the ethnic affiliated political party continued among the major ethnic political parties. The parties were the Unity Party of Nigeria (UPN) under the leadership of Chief Obafemi Awolowo. Unity Party of Nigeria (UPN) held sway in the Southwest among the Yorubas. The National Party of Nigeria (NPN) had its major supporters based in the Northern part of Nigeria among the Hausa/Fulanis populace, while the Nigeria People's Party (NPP), presided over by Dr. Nnamdi Azikiwe and held sway in the Southeastern Nigeria among Igbos ethnic group. These Second Republic political parties were the offshoot of the First Republic Action Group (AG), Northern People Congress (NPC) and National Council for Nigerian Citizens (NCNC) respectively. Although there were other two minority parties, Great Nigeria Peoples Party (GNPP), Peoples Redemption Party (PRP) and later National Advanced Party (NAP) that were formed. These political parties were not different from others as they equally took on their ethnic colouration and affiliation of minority's ethnic groups teaming together. The consequence of ethnic and prebendal politics according to Ojo (2014) is 'pauperizing democratic dividends of the citizens in Nigeria'.

In the third republic the military governments under General Babangida manipulated the formation of political parties. He formed and registered two political parties- the Social Democratic Party (SDP) and National Republican Convention (NRC). In spite of the fact that the political parties' formation was the handiwork of the then Military government, yet, ethnicity affiliation and traits were still noticeable in the membership composition of the parties, such that SDP drawn majority of its members from the southern part of the country, while NRC had majority of its members among the Hausa/Fulani of the northern part of the country.

In the fourth republic, the initial political parties that were provisionally registered were nine, out of which three of them were fully registered to contest after the Local Government elections. These three political parties are the Peoples' Democratic Party (PDP), the All People's Party (APP) later known as All Nigerian Peoples Party (ANPP) and the Alliance for Democracy (AD). In the Fourth Republic, despite that, a Yoruba man was elected as president under PDP, yet the ethnic political ideas still manifested. For instance, ANPP was considered as a party predominantly occupied by the Hausa/Fulani while AD was seen as a direct link of the First Republic Action Group and Second Republic Unity Party of Nigeria. This was also evident in the number of states won by the AD which covers the six Southwestern states of the nation (Azeez, 2009).

\section{Ethnic Gang-up}

Alliances and coalitions is one of the characteristics features of politics in most multi-ethnic nations of the World. Due to the fact that ethnic competition and rivalry for the control of governmental activities has constantly undermined the emergence of political parties with national outlook as well as overall acceptable national political leaders, there is therefore a need for coalition. In democratically nations of the world, the constitutions usually demand that national governments are constituted by the parties with the overall majority of total votes cast during the general elections; given the fact that it is always difficult to achieve this, alliances and coalitions are needed in order to cover up the deficiency recorded in the election. Alliances in Nigeria context are the one whereby the pact is based on ethnic sentiments and gang-up involving political manipulation, manoeuvrings, calculations and permutation.

The political party's formation is always based on ethnic scheming and gang-up against other ethnic group with the intention of dominating the political atmosphere of the nation. Thus, it is not surprising that most of the political parties so emerged to contest for political power since Nigeria's independence relies so much on "mobilizing primordial ethnic/religious sentiments to capture power at the centre" (Uka, n.d.). The far reaching impact of the ethnic gang-up to control political power is better comprehended by the astounding revelation and lamentation of the then Chairman of the National Electoral Commission, Professor Humphrey Nwosu. He aptly captured the Nigeria's political scenario of ethnic politics and political gang-up even before the independence. According to Nwosu as cited in Uka (n.d:10)

Our party system, from its inception in the late 1940s and early 1950s, reflected the injection of ethnicity into our political system. In due course, the major political parties and minor ones became vehicles for the representation, protection and aggregation of ethnic interests. Our political leaders, by and large, exploited ethnic ties and symbols to promote their selfish interest and to consolidate themselves in power in their regional enclaves. The regionalization of politics, which our early experiment with quasi-federal 
government in the early 1950 s represented, also fed and encouraged the ethnicization of our party system. The failure of our pioneer political class was their inability to rise above ethnic questions at a time when the dynamics of our federalization was, paradoxically, moving towards the federalization of our party system.

\section{Ethnic Politics in some African Nations}

In our contemporary time, nearly all the political conflicts found in Africa are attributable to ethnic groups competing for the control of political power of their different nations (Aquiline, 2008; Nzongola-Ntalaja, 1999). Nation such as - Angola, Nigeria, Sudan, and Ethiopia, Somalia, Rwanda, Burundi, Liberia, and Sierra Leone are seriously enmeshed in the politics of ethnicity (Aquiline, 2008). In many African nations, the struggle for the control of political power from time to time, brought different ethnic groups into conflict, such that, each ethnic group 'advocates its interests in different ways' in order to secure a place in the political leadership with the intention of having access to the nation economy. Thus, ethnic group could also be seen as interest groups whose members share some common economic and political interests (Robert, 1983). In similar vein, Eifert, Miguel and Posner (2010) argue that ethnic identities in Africa are strengthened by exposure to political competition. Different reasons had being adjudged for the flourishing of ethnicity in Africa. For instances, ethnicity are useful in the competition for political power; it is a powerful reasons of behaviour; it is a tool for mobilizing people; and it is an instrument of coalitions force for wrestling for the nation's economy power.

Olaiya (2014) equally acknowledges that in present-day Africa, ethnicity played a vital role in shaping African political systems. He further states that ethnicity preceded African nations' independence, and that the colonial leaders are not interested in stamping out ethnicity, but 'to stem the expressions of nationalism they produce'. European imperialists play Africans against themselves through selection of their Africans loyalists without involving the majority of African population. Thus, to a large extent, colonizers planted and promote ethnicity which was later germinated into 'democratic and governance misadventures' that covers most post-colonial Africa nations.

Similar to Olaiya's position, Chogugudza (2008) in his work Ethnicity Main Cause of Instability, Civil Conflict and Poverty in Africa, observes that some of the colonial officers planted ethnic rivalries amongst indigenous populations by employing a strategy of 'divide and rule' in the various colonized places. The divide and rule strategy adopted generated mutual suspicions among different ethnic groups in many African nations a situation which persist even till now. Many political leaders across Africa used ethnicity to their advantages. They make use of ethnicity in establishing themselves perpetually in power and dealt decisively with perceived political opponents.

Chogugudza (2008) notes that ethnicity continue to threaten the stability of South Africa, he cited the recent unseating of President Thabo Mbeki by his deputy Jacob Zuma from the leadership of the African National Congress (ANC), the strongest political party in South Africa to have been influenced by ethnicity. In Sudan, the Darfur political crisis is traceable to ethnicity, the Northern Sudan over the years have been dominating the political activities of Sudan and have maltreated severely the ethnic groups of Southern Sudan as they (the ethnic groups of South Sudan) continue to groan under the oppressive rule of the ethnic groups of Sudan Northern extractions.

According to Aquiline-Tarimo (2008) ethnic identities manipulation has been one of the challenges 'tearing Kenya apart'; and inability of the Kenyan people to integrate ethnic identities into their nation's structure has worsen the situation. It is understandable that Kenya like many other nations in Africa is a multi-ethnic society who has lived peacefully for many years. However, the recent happening in Kenya has shown that the dominant ethnic groups constitute a major political problem within the nation. According to Aquiline-Tarimo (2008:1)

In recent years, however, the dominant ethnic groups have been on the forefront in fighting for political power. This situation has resulted into fighting to control the state. The relatively less dominant communities have been playing the card of opportunism...The situation has fomented anger, resentment, lust for revenge, and aggressive competitiveness that has overlooked the common good of the entire country. Frustration among the poor, both in urban and rural areas, has created a growing tendency to use violence as a viable means to correct the situation.

Ethno-political competition which started since Kenya's independence continued unabated and degenerated into ethno-political competition, discrimination, and violence. After the December 2007 election for example, ethnic rivalry resulted into violence where hundreds of people were killed and many properties were destroyed (Aquiline-Tarimo, 2008). 


\section{Ethnic Politics and its Implication on the Nation's Development}

Politics of ethnicity has made it difficult for Nigeria to have the right leaders in its political sojourn over fifty four years of independence, except for a very few of her leaders who have demonstrated total commitment to the nation's development. Ethnic politics has been a clog in the wheel of political advancement of the nation such that, there has never been a leader with national outlook that has emerged in Nigeria. The election of candidates so far, has been based on 'where the candidates came from rather than on the right candidates for the election' (Umezinwa, 2012).

The consequence of which 'political dealers' instead 'leaders' have been emerging in the nation's political activities. These so called leaders are without the interest of the nation at heart. They emerge to political limelight through ethnic sentiments, but end up in disappointing their so call ethnic group; this is evident in almost all parts of the nation where none of the ethnic nation is developed. One would have expected that owing to the way many of these politicians came to power via ethnic sympathy, they would satisfy the ethnic group that supported them to power, but as soon as they emerge, they neglect their people. Many of them who are at Abuja the Federal Capital Territory refused to go back to see their people at home again.

The issue of the federal character is another political arrangement that is troubling the political advancement of the nation. Although the motive behind the enshrinement of the principle is to enhance equality and fairness among the component ethnic groups in Nigeria, with a view to bringing sense of belonging into different citizens of Nigeria as well as to prevent or resist fears of domination of one region or ethnic group over the others. The plausibility of the principle notwithstanding, it brings about the reigning of mediocrity into the governmental activities in the name of equity and fairness among the component states. Given the fact that merit has been overruled as a criterion for serving the nation, it is not surprising that all manners of people have been appointed to hold public offices in which they neither had the training nor the experience. Thus, in a situation like this, there is no way any progress could be achieved in the nation building and advancement (Umezinwa, 2012). Umezinwa further states that ethnic politics and rivalry also leads to the emergence of incompetent president. For instance, Nigeria adopted the rotational presidency among the six geopolitical zones order to defuse ethnic tension, the consequent of which the president is not elected based on merit but rather on the basis of where the aspirant comes from.

Similarly, ethnic politics has also created an avenue whereby corrupt leaders are being supported by their ethnic groups. Instead of the citizens to vehemently reject corrupt leaders and condemn their activities, they do support them due to ethnicity and ethnic politics, thereby, make these leaders continue in the corruptive manner with impunity. Corruption without mincing words has been undermining Nigeria's political development. It has permeated all levels of government in Nigeria while ethnic group of the corrupt politician are always defending them.

The consequence of corruption on Nigerians is devastating. For instance, despite the enormous oil and gas deposit in Nigeria, the nation remains poor with over 90 million Nigerians living in abject poverty. Since the discovery of oil in large quantity in Nigeria, the nation has earned over $\$ 300$ Billion from oil exports (Ribadu, 2004, cited in Arowosaiye and Kulliyyah, 2009) but there was nothing considerably to show for it. Corruption has cost Nigerians her whooping sum of $£ 20$ Billion Pounds (about $\$ 500$ Billion) which has been stolen since independence to date by past leaders of the country. The money stolen could have made Nigeria six times better than Western Europe where many Nigerians are now running to (Ribadu 2006 cited in Arowosaiye and Kulliyyah, 2009).

Ethnic politics no doubt has had a lot of negative consequences for the nation's movement towards democratic advancement. The resultant effect of ethnic politics as pointed out by Babangida (2002) cited in Salawu and Hassan (2011), are

wastage of enormous human and material resources in ethnically inspired violence, encounters, clashes and even battles, heightening of fragility of the economy and political process, threat to security of life and property and disinvestments of local and foreign components with continuous capital flight and loss of confidence in the economy; and increasing gaps in social relations among ethnic nationalities including structural suspicions and hate for one another. Ethnic nationalism is equally responsible for upspring of ethnic militias across the country; the Oodua Peoples Congress of the southwest, Arewa Peoples Congress in the north and Egbesu in the east among others (Babangida, 2002 cited in Salawu and Hassan, 2011:32). 


\section{Conclusion}

This study has shown that Nigeria's pluralistic nature has made her susceptible to conflicts arises from pursuit of divergent interest. The incessant struggle for political positions among different ethnic groups in order to control economic wealth of the nation no doubt is a threat to the sustenance of democratic governance. The sole ambition of controlling the economic activities of the nation has led to 'keen hunt', for political power especially at the centre by the various ethnic groups in Nigeria. The political calculation and permutation of who gets what, when, and how of the political cum economic potentialities of the nation are the main sources of hostility and conflicts that has continued to threaten the political stability and advancement of Nigeria as a nation. The incessant struggle for power is always heating-up the nation's polity. Apart from the fact that this action has continued to polarize the nation along ethnic groups divides, the degree of human losses in every political violence associates with power struggle is unquantifiable. Nigeria's democracy has been characterized by ethnic-based politics since independence up till the third republic, such that different ethnic group is affiliated with one political party or the other.

Thus, Nigeria needs to imbibe the spirit of fairness and equity. Where there is equity and fairness in governance in a nation, such a nation will experience national unity and peace. These are essential ingredients for nation's development, progress, stability and national integration.

\section{References}

Ako-Nai, R. (2008). The politics of "marginalization" in Nigeria: Challenges of the 4th Republic. In D. Oni (Ed.), Nigeria and globalization discourses on identity politics and social conflict. Lagos: Centre for Black and African Arts and Civilization (CBAAC).

Anugwom, E. (2000). Ethnic conflict and democracy in Nigeria: The marginalisation question. Journal of Social Development in Africa, 15(1), 61-78. http://dx.doi.org/10.4314/jsda.v15i1.23854

Aquiline-Tarimo, S. J. (2008). Politicization of ethnic identities and the common good in Kenya. Paper delivered at an Ethics at Noon Presentation, 2 April 2008, at Stanford University, California.

Arowosaiye, Y. I., \& Kulliyyah, A. I. (2009). The devastating impact of money laundering and other economic and financial crimes on the economy of developing countries: Nigeria as a case study. A publication of the University of Ilorin, Ilorin, Kwara State, Nigeria. Retrieved from http://www.uniilorin.edu.ng/publications

Azeez, A. (2004). The dynamics of ethnic politics and democratic consolidation in Nigeria: A prognosis. In D. Oni, S. Gupta, T. Omoniyi, E. Adegbija, \& S. Awonusi (Eds.), Nigeria and globalization: discourses on identity politics and social conflict (pp. 327-342). CBAAC: Ibadan: Stirling-Horden Publishers (Nig.) Ltd.

Azeez, A. (2009). Ethnicity, party politics and democracy in Nigeria: Peoples Democratic Party (PDP) as agent of consolidation? Kamla-Raj, Studies Tribes Tribals, 7(1), 1-9.

Brubaker, R., Loveman, M., \& Stamatov, P. (2004). Ethnicity as cognition. Theory and Society, 33, 31-64. http://dx.doi.org/10.1023/B:RYSO.0000021405.18890.63

Chogugudza, C. (2008). Ethnicity main cause of instability, civil conflict and poverty in Africa. Retrieved February 20, 2015, from http://www.africaresource.com/essays-a-reviews/politics/478-ethnicity-main-cause-of-instability-civil-confl ict-and-poverty-in-africa

Cohen, A. (1974). The lesson of ethnicity. In A. Mayor (Ed.), Urban ethnicity, ASA Monographs 12. London: Tavistock Publication.

Eifert, B., Miguel, E., \& Posner, D. N. (2010). Political competition and ethnic identification in Africa. American Journal of Political Science, 54(2), 494-510. http://dx.doi.org/10.1111/j.1540-5907.2010.00443.x

Ekpo, A. H. (2010). Federal Republic of Nigeria. Retrieved March 20, 2014, from http://www.forumfed.org/libdocs/Global_Dialogue/Book_4/BK4-en-ng

Gordon, M. (1964). Assimilation in American life. New York: Oxford University Press.

Mclean, B. (1991). Multicultural studies. In C. Marsh (Eds.), Teaching of Social Studies and Environment. Sydney: Prentice Hall.

Mustapha, A. R. (2007). Institutionalising ethnic representation: How effective is the Federal Character Commission in Nigeria? CRISE Working Paper No. 43, Centre for Research on Inequality, Human Security and Ethnicity (CRISE), University of Oxford, U.K. 
Nzongola-Ntalaja, G. (1999). Ethnicity and State Politics in Africa. African Journal of International Affairs, 2(1), 31-34. http://dx.doi.org/10.4314/ajia.v2i1.27239

Ojo, J. S. (2014). Prebendalism, socio-linguistic and ethnic politics: The bane of Nigerian democracy. International Journal of Politics and Good Governance, 5(1), 1-21.

Okotoni, O. (2006). Governance, taxation and fiscal policy in Nigeria. European Journal of Social Sciences, 2(2), 80-94.

Olaiya, T. A. (2014). Youth and ethnic movements and their impacts on party politics in ECOWAS member states. Sage Open, 1-12. Retrieved from http://www.sagepublications.com

Orewa, G. O. (1997). We are all guilty: The Nigerian crisis. Ibadan: Spectrum Books Ltd.

Osaghae, E. E. (1995). Structural adjustment and ethnicity in Nigeria. Uppsala: Nordic African Institute.

Owete, F. (2014). Northern minorities protest 'marginalization' by Hausa-Fulani. Retrieved October 23, 2014, from https://www.premiumtimesng.com/nationalconference/northern-minorities-protest-marginalizationhausa-fulani

Rakov, S. A. (1990). Ethnicity in Nigeria. African Postcolonial Literature in English web. Retrieved from http://www.postcolonialweb.org/nigeria/ethnicity.html

Ribadu, N. (2004). The Role of EFCC in sanitising the Nigerian economic environment in a democratic setting. Being a paper presented at the Adamawa Economic Conference and Financial Exhibition, between 9th-10th December, 2004.

Robert, H. B. (1983). Modernization, ethnic competition and the rationality of politics in contemporary Africa. In D. Rothchild, \& V. A. Olorunsola (Eds.), State versus ethnic claims: African policy dilemmas. Boulder, Colorado: Westview Press.

Rose, P. (1965). They and we. New York: Random House.

Salami, Y. K. (2004). Ethnic pluralism and national identity in Nigeria. In R. D. Coates (Ed.), Race and ethnicity across time, space, and discipline (pp. 397-405). Boston: Brill Leiden.

Salawu, B., \& Hassan, A. O. (2011). Ethnic politics and its implications for the survival of democracy in Nigeria. Journal of Public Administration and Policy Research, 3(2), 28-33.

Sanda, A. O. (1976). Ethnicity relations in Nigeria. Ibadan: The Caxton Press (West Africa) Ltd.

Sklar, R. (1967). Political science and political integration. Journal of Modern African Studies, V(1), 6-7.

Trading Economics. (2014). Nigeria population 1960-2014. Retrieved December 4, 2014, from http://www.tradingeconomics.com/nigeria/population

Uka, E. M. (n. d.). Ethnic, religious and communal conflict in Nigeria: Implications for security. Society for Research and Academic Excellence. Retrieved from http://www.academicexcellencesociety.com/ethnic_religious_and_communal_conflict_in_nigeria.html

Umezinwa, C. (2012). Ethnicity and Nigeria's underdevelopment. A New Journal of African Studies, 9, 215-229. http://dx.doi.org/10.4314/og.v9i1.11

\section{Copyrights}

Copyright for this article is retained by the author(s), with first publication rights granted to the journal.

This is an open-access article distributed under the terms and conditions of the Creative Commons Attribution license (http://creativecommons.org/licenses/by/3.0/). 